\title{
Acute Effects of Sulphur Mustard Gas on the Number of Lymphocytes in the Rat's Spleen
}

\author{
Efectos Agudos del Gas Mostaza sobre el Número de Linfocitos en el Bazo de Rata \\ *Jahanshahi Mehrdad; **Bahadoran H. \& **Asadi M. H.
}

MEHRDAD, J.; BAHADORAN, H. \& ASADI, M. H. Acute effects of Sulphur mustard gas on the number of lymphocytes in the rat's spleen. Int. J. Morphol., 26(2):432-436, 2008.

SUMMARY: Sulphur mustard (SM), commonly known as mustard gas is an alkylating agent that causes serious blisters upon contact with human skin. SM is frequently used as a chemical warfare agent. There is some evidence for sulfur mustard-induced lymph system effects in humans. Between 2000-2001, 42 male albino Wistar rats were used. After accommodation with environment, we divided rats to control, sham and experimental groups $(2.5 \mathrm{mg} / \mathrm{kg}, 5 \mathrm{mg} / \mathrm{kg}, 10 \mathrm{mg} / \mathrm{kg}, 20 \mathrm{mg} / \mathrm{kg}$ and $40 \mathrm{mg} / \mathrm{kg}$ ). Then we injected sulphur mustard oil in rat's intraperitoneal space. Then their spleens were removed for histological verification. Our results showed that significant difference in lymphocytes number in experimental groups after 24 hours. The number of lymphocytes in 5, 10, 20 and $40 \mathrm{mg} / \mathrm{kg}$ groups was increased and this increase in $40 \mathrm{mg} / \mathrm{kg}$ group was more than the other groups. We concluded that the number of lymphocytes increased due to exposure of mustard gas and there is a relationship between the increase of lymphocytes and dose of exposure.

KEY WORDS: Mustard gas; Lymphocytes; Spleen.

\section{INTRODUCTION}

Sulphur mustard (SM), commonly known as mustard gas and chemically, bis [2-chloroethyl] sulphide is an alkylating agent that causes serious blisters upon contact with human skin. SM is frequently used as a chemical warfare agent (Wormser, 1991; Eisenmenger et al., 1991; Momeni et al., 1992). Due to the simple method of preparation, SM being used clandestinely during war or by terrorist groups still remains a threat, inspite of the successful implication of the Chemical Weapons Convention (Krutzsch \& Trapp, 1994). SM forms sulphonium ion in the body and alkylates DNA leading to DNA strand breaks and cell death (Papirmeister et al., 1991; Rao et al., 1999). Due to the high electrophilic property of the sulphonium ion, SM binds to a variety of cellular macromolecules (Somani \& Babu, 1989). Eyes, skin and the respiratory tract are the principal target organs of SM toxicity (Papirmeister et al.; Balali, 1984; Vijayaraghavan, 1997).

Several animal studies indicate effects of sulfur mustard on the hemopoietic system following intravenous or subcutaneous administration of sulfur mustard (Kindred, 1947).
There is some evidence for sulfur mustard-induced lymph system effects in humans. Lymph node discoloration and spleen pathology were found in autopsies of sulfur mustard victims (Alexander, 1947). Additional animal studies also indicated sulfur mustard-induced damage to the lymph system (Cameron et al., 1946; Coutelier et al., 1991; Venkateswaran et al., 1994).

Sulfur mustard tissue distribution data from an Iranian soldier who died 7 days after inhalation and/or dermal exposure to sulfur mustard indicated distribution: brain $>$ kidney $>$ liver $>$ spleen $>$ lung (Drasch et al., 1987), whereas radiolabel concentration data in rats 4 days after an intravenous injection of radiolabeled sulfur mustard indicate a different distribution pattern to these organs: kidney $>$ lung $>$ liver > spleen > brain (Maisonneuve et al., 1994).

Since there are rare documents about the number of lymphocytes in spleen after exposure of mustard gas, therefore the aim of this study was evaluation of the lymphocytes number in the rat's spleen after 24 hours of exposure of mustard gas.

\footnotetext{
* PhD. Assistant Professor of Anatomy, Department of Anatomy, Gorgan University of Medical Sciences, Gorgan, Iran.

** PhD. Associate Professor of Anatomy, Department of Anatomy, Baghiyatallah University of Medical Sciences, Tehran, Iran.
} 


\section{MATERIAL AND METHOD}

Between 2000-2001 years, 42 male albino Wistar rats (250 - $300 \mathrm{~g}$ ) obtained from Pasteur institute of Iran were used. Rats were housed in large plastic cage, food and water were available. Animals were maintained under standard conditions and $12 \mathrm{~h} / 12 \mathrm{~h}$ light / dark cycle with lights on at 7.00 a.m. After accommodation with environment, we divided rats to control, sham and experimental groups (2.5 $\mathrm{mg} / \mathrm{kg}, 5 \mathrm{mg} / \mathrm{kg}, 10 \mathrm{mg} / \mathrm{kg}, 20 \mathrm{mg} / \mathrm{kg}$ and $40 \mathrm{mg} / \mathrm{kg}$ ) according of Coutelier report in 1991 (Coutelier et al.); in each group we had 6 rats.

We mixed the sulphur mustard oil with the Tyrods buffer and then we injected this solution in intraperitoneal space according the rats weight. For sham group we injected the buffer without the mustard.

After examinations, animals were dissected after ether anesthesia and their spleen were removed for histological verification, at first the spleens fixed in Buoin solution and two weeks later impregnated with paraffin wax. After histological processing, slices of $5 \mu \mathrm{m}$ (serial section of anterior to posterior of spleens) were produced with Leitz rotary microtome (Microm, Germany, HM, 325) (One of 10 sections were selected for staining and morphometeric measurements). For staining, haematoxylin-eosine (H\&E) staining was used.

Morphometric measurement were carried out using on Olympus DP 12 digital camera and BX 51 microscope (Olympus Optical Co. LTD, Tokyo, Japan). We selected a field $\left(100000 \mu \mathrm{m}^{2}\right)$ within the spleens. Randomly selected, non-overlapping photographs using a $\times 40$ objective lens were taken from the designated areas. Images were saved by the Bioreporter program and further processed using the Adobe Photoshop 6.0 program (Adobe System Inc., San Jose, CA, USA).

Table 1. The mean of lymphocytes number in control, Sham and experimental groups $\mathrm{P}<0.01$ is significant.

\begin{tabular}{|c|c|c|c|c|}
\hline P-value & Std. Deviation & Area & Mean & Group \\
\hline NS & 24.1 & $\mu \mathrm{m}^{2} \quad 100000$ & 1440 & Control \\
\hline NS & 12.1 & $\mu \mathrm{m}^{2} \quad 100000$ & 1410 & Sham \\
\hline NS & 8.9 & $\mu \mathrm{m}^{2} \quad 100000$ & 1394 & $2.5 \mathrm{mg} / \mathrm{kg}$ \\
\hline $\mathrm{P}<0.01$ & 26 & $\mu \mathrm{m}^{2} \quad 100000$ & 1596 & $5 \mathrm{mg} / \mathrm{kg}$ \\
\hline $\mathrm{P}<0.01$ & 14.2 & $\mu \mathrm{m}^{2} \quad 100000$ & 1631 & $10 \mathrm{mg} / \mathrm{kg}$ \\
\hline $\mathrm{P}<0.01$ & 62.6 & $\mu \mathrm{m}^{2} \quad 100000$ & 1568 & $20 \mathrm{mg} / \mathrm{kg}$ \\
\hline $\mathrm{P}<0.01$ & 5.6 & $\mu \mathrm{m}^{2} 100000$ & 1632 & $40 \mathrm{mg} / \mathrm{kg}$ \\
\hline
\end{tabular}

For cell counts, photographs at a magnification of x40 (objective lens) were taken throughout the longitudinal axis of the spleen and further processed as described above. All of the lymphocytes shown on thisfield were counted and then the mean and SD of lymphocytes number were measured.

Statistical analysis. Data was expressed as mean SD differences among areas were statistically evaluated using the one-way analysis of variance (ANOVA). Probabilities of $\mathrm{P}<0.01$ were considered significant.

\section{RESULTS}

Immediately after the injection of mustard solution, the rats secluded to one corner of cage. The mean and SD of the number of lymphocytes (per $105 \mu \mathrm{m}^{2}$ ) in control, sham and experimental groups are depicted on Table I.

There were not significant differences in lymphocytes number between control and sham groups, also between sham and $2.5 \mathrm{mg} / \mathrm{kg}$ differences were not significant, but the differences between sham and $5 \mathrm{mg} / \mathrm{kg}$ groups, between sham and $10 \mathrm{mg} / \mathrm{kg}$ groups, between sham and $20 \mathrm{mg} / \mathrm{kg}$ groups and also between sham and $40 \mathrm{mg} / \mathrm{kg}$ groups were significant.

The number of lymphocytes in $40 \mathrm{mg} / \mathrm{kg}$ group was more than the other groups and in $2.5 \mathrm{mg} / \mathrm{kg}$ group it was less than the other groups.

\section{DISCUSSION}

The short time effects of mustard oil indicate that the number of lymphocytes increased due to the interance of pathogenic matter, and the lymphocytes reaction against it via the proliferation or migration. We found there is a relationship between dose of exposure and increase of lymphocytes number. The related documents about the effects of mustard gas on the spleen are as follow:

Venkateswaran et al. reported that sulfur mustard was topically applied a single time at doses of $3.88,7.75$, or $15.5 \mathrm{mg} / \mathrm{kg}$ to the shaved backs of Balb/c mice (16/group/ 
dose). Sulfur mustard produced a significant dose-related decrease in the weight of the spleen (12-59\%), and peripheral (12-44\%) and mesenteric lymph nodes (significant only at high dose, 18\%). Incidence and severity of histological changes in the thymus and spleen were also dose-related. Spleen histopathology included hypocellularity, atrophy of the lymphoid follicles, degeneration of germinal centers, and red pulp infiltrated with macrophages.

A significant dose-related decrease in the cellularity of the spleen (24-45\%) was measured. A dose-related decrease in the cellularity of the thymus was also found, significant at the mid and high doses (36-42\%) (Venkateswaran et al.).

Coutelier et al. reported that: A significant doserelated reduction in spleen cell number was measured in mice 7 days after intraperitoneal injection of sulfur mustard (23\% at $5 \mathrm{mg} / \mathrm{kg}$ and $49 \%$ at $10 \mathrm{mg} / \mathrm{kg}$ ). A $26 \%$ increase in spleen T-lymphocytes and a 44\% decrease in B-lymphocytes were measured 7 days following injection with $10 \mathrm{mg} / \mathrm{kg}$ of sulfur mustard (Coutelier et al.).

Also Cameron et al., Coutelier et al. and Venkateswaran et al. showed that sulfur mustard-induced damage to the lymph system and lymph node discoloration and spleen pathology were found in autopsies of sulfur mustard victims.

Consistent with observations of the human spleen, Pant \& Vijayaraghavan (1999) measured a significant 38\% reduction in spleen-to-body weight ratio in mice exposed to $84.7 \mathrm{mg} / \mathrm{m}^{3}$ for 1 hour. In the majority of cases, the spleen was described as shrunken in size with pale color. Microscopically only 2 of 32 spleens examined showed degeneration or necrosis; pyknosis and karyorrhexis of lymphocytes in some corpuscles was observed in one and slight necrosis of the malpighian follicle in the other (Pant \& Vijayaraghavan).

Kindred in 1947 reported that single intravenous injection of $0.5 \mathrm{mg} / \mathrm{kg}$ of sulfur mustard dissolved in thiodiglycol in young male rats caused degenerative damage to the spleen, thymus, and bone marrow.

As the mention studies were in long period of exposure, therefore they showed decrease of lymphocytes, number in spleen, but in our study the number of lymphocytes counted after 24 hours and in this time due to immunological responses the number of lymphocytes was increased.

We concluded that there is a dose-related increase in number of lymphocytes due to exposure of mustard gas.
MEHRDAD, J.; BAHADORAN, H. \& ASADI, M. H. Efectos agudos del gas mostaza sobre el número de linfocitos en el bazo de rata. Int. J. Morphol., 26(2):432-436, 2008.

RESUMEN: El sulfuro de mostaza (SM), comúnmente conocido como gas mostaza, es un agente alquilante que causa graves ampollas en contacto con la piel humana. SM se utiliza con frecuencia como un agente de guerra química. Hay algunas evidencias que indican que el SM induce efectos en el sistema linfático en seres humanos. Entre los años 2000-2001, fueron utilizadas 42 ratas albinas Wistar macho. Después de la acomodación con el medio ambiente, las ratas se dividieron en grupos control, impostor y experimental $(2,5 \mathrm{mg} / \mathrm{kg}, 5 \mathrm{mg} / \mathrm{kg}, 10 \mathrm{mg} / \mathrm{kg}, 20 \mathrm{mg} / \mathrm{kg}$ y $40 \mathrm{mg} / \mathrm{kg}$ ). Luego se inyectó aceite de $\mathrm{SM}$ en el espacio intraperitoneal de las ratas. A continuación, sus bazos fueron removidos para la verificación histológica. Los resultados mostraron una diferencia significativa en el número de linfocitos en el grupo experimental después de 24 horas. El número de linfocitos en los grupos de 5, 10, 20 y $40 \mathrm{mg} / \mathrm{kg}$ fue mayor siendo este incremento en el grupo de $40 \mathrm{mg} / \mathrm{kg}$ más alto que en los otros grupos. Concluimos que el número de linfocitos aumenta debido a la exposición de gas mostaza existiendo una relación entre el aumento de linfocitos y la dosis de exposición.

PALABRAS CLAVE: Gas mostaza; Linfocitos; Bazo.

\section{REFERENCES}

Alexander, S. F. Medical report of the Bari Harbor mustard casualties. Military Surgeon, 101:1-17, 1947.

Balali, M. Clinical and laboratory findings in Iranian fighters with chemical gas poisoning. Arch. Beges., Suppl:254$9,1984$.

Cameron, G. R.; Gaddum, J. H. \& Short, R. H. D. The absorption of war gasses by the nose. J. Pathol. Bacteriol., 58:449-55, 1946.

Coutelier, J. P.; Lison, D.; Simon, O. \& Willems, J. Effect of sulfur mustard on murine lymphocytes. Toxicol. Lett., 58(2):143-8, 1991.

Drasch, G.; Kretschmer, E.; Pahrm, M., et al. Concentrations of mustard gas bis-2-chloroethylsulfide in the tissue of a victim of a vesicant exposure. J. Forensic Sci., 32:178893, 1987.

Eisenmenger, W.; Drasch, G.; Von Clarmann, M.; Kretschmer, E. \& Roider, G. Clinical and morphological findings on mustard gas [bis(2-chloroethyl) sulphide] poisoning. J. Forensic Sci., 36:1688-98, 1991. 
MEHRDAD, J.; BAHADORAN, H. \& ASADI, M. H. Acute effects of Sulphur mustard gas on the number of lymphocytes in the rat's spleen. Int. J. Morphol., 26(2):432-436, 2008.

Kindred, J. E. Histological changes occurring in the hemopoietic organs of albino rats after single injections of 2-chloroethyl vesicants: A quantitative study. Arch. Path., 43:253-95, 1947.

Krutzsch, W. \& Trapp, R. A commentary on the chemical weapons convention. London, Martinus Nijhoff Publishers, 1994. p.543.

Maisonneuve, A.; Callebat, I.; Debordes, L. \& Coppet, L. Distribution of [14C]sulfur mustard in rats after intravenous exposure. Toxicol. Appl. Pharmacol., 125(2):281-7, 1994.

Momeni, A. Z.; Enshaeih, S.; Meghdadi, M. \& Amindjavaheri, M. Skin manifestations of mustard gas. A clinical study of 535 patients exposed to mustard gas. Arch. Dermatol., 128:775-80, 1992.

Pant, S. C. \& Vijayaraghavan, R. Histomorphological and histochemical alterations following shortterm inhalation exposure to sulfur mustard on visceral organs of mice. Biomed. Environ. Sci., 12:201-13, 1999.

Papirmeister, B.; Feister, A. J.; Robinson, S. I. \& Ford, R. D. Medical defense against mustard gas: toxic mechanisms and pharmacological implications. Boca Raton, CRC Press, 1991.

Rao, P. V. L,; Vijayaraghavan, R. \& Bhaskar, A. S. B. Sulphur mustard induced DNA damage in mice after dermal and inhalation exposure. Toxicology, 139:39-51, 1999.

Somani, S. M. \& Babu, S. R. Toxicodynamics of sulphur mustard. Int. J. Clin. Pharmacol. Ther. Toxicol., 27:41935, 1989.

Venkateswaran, K. S.; Neeraja, V.; Sugendran, K.; Gopalan, N.; Vijayaraghavan, R.; Pant, S. C.; Prakash, A. O. \& Malhotra, R. C. Dose dependent effects on lymphoid organs following a single dermal application of sulphur mustard in mice. Hum. Exp. Toxicol., 13(4):247-51, 1994.

Vijayaraghavan, R. Modifications of breathing pattern induced by inhaled sulphur mustard in mice. Arch. Toxicol., 71:157-64, 1997.

Wormser, U. Toxicology of mustard gas. Trends Pharmacol. Sci., 12:164-7, 1991.
Correspondence to:

Dr. Mehrdad Jahanshahi

Department of Anatomy

Gorgan University of medical Sciences

Gorgan, IRAN

Tel: 0098-171-4421651

P.O. Box: $49175-553$

E-mail: mejahanshahi@yahoo.com

Received: 15-12-2007

Accepetd: 07-02-2008 